\title{
Profil Pelaksanaan Program Adiwiyata dan Sikap Peduli Lingkungan di SMPN Adiwiyata Tingkat Provinsi di Tanjungpinang Tahun 2018
}

\author{
Erda Muhartati ${ }^{1}$, Nur Eka Kusuma Hindrasti ${ }^{2 *}{ }^{*}$ Afriliani $^{3}$ \\ ${ }^{1,2,3}$ Universitas Maritim Raja Ali Haji, Kota Tanjungpinang, Kepulauan Riau 29115, Indonesia
}

Pengiriman: 16 Juni 2019; Diterima: 23 Juli 2019; Publikasi: 28 Juli 2019

\begin{abstract}
Abstrak
Penelitian ini bertujuan untuk mendeskripsikan pelaksanaan program adiwiyata di SMPN adiwiyata tingkat provinsi yang mencakup 4 komponen program adiwiyata dan mendeskripsikan sikap peduli lingkungan guru dan siswa. Penelitian ini merupakan penelitian kombinasi meliputi penelitian deskriptif kualitatif untuk mendeskripsikan pelaksanaan program adiwiyata menggunakan instrumen rubrik oservasi dan penelitian deskriptif kuantitatif untuk mendeskripsikan sikap peduli lingkungan guru dan siswa menggunakan instrumen angket dan pedoman wawancara. Hasil penelitian menunjukkan bahwa: (1) (a) Kebijakan sekolah berwawasan lingkungan, meliputi adanya visi misi yang berkaitan dengan lingkungan, RKAS $20 \%$ untuk program lingkungan. (b) Pelaksanaan kurikulum berbasis lingkungan, meliputi perencanaan dan pelaksanaan pedidikan lingkungan hidup terintegrasi dalam mata pelajaran. (c) Kegiatan lingkungan berbasis partisispatif, meliputi pemeliharaan gedung dan lingkungan, kegiatan ekstrakurikuler, kreativitas dan inovasi, serta kerjasama dengan orang tua hingga instansi pemerintah. (d) Pengelolaan sarana pendukung ramah lingkungan, meliputi kelengkapan sarana, pemeliharaan sarana, hemat energi dan pelayanan kantin sehat. (2) Hasil sikap peduli lingkungan guru dan siswa di SMPN adiwiyata tingkat provinsi pada kategori sangat baik. Pelaksanaan program adiwiyata di SMPN Adiwiyata Tingkat Provinsi di Tanjungpinang Tahun 2018 yang sudah sudah sesuai dengan standar program adiwiyata tingkat provinsi yang telah ditentukan oleh Kementerian Lingkungan Hidup dan Kementerian Pendidikan dan Kebudayaan. Hasil tersebut selaras dengan sikap peduli lingkungan guru dan siswanya yang sangat baik.
\end{abstract}

Kata kunci: Pelaksanaan Program Adiwiyata, Adiwiyata Tingkat Provinsi, Sikap Peduli Lingkungan

\section{Abstract}

This study aimed to describe the implementation of the adiwiyata program at the provincial adiwiyata junior high school which includes 4 components of the adiwiyata program and describes the caring of environment of teachers and students. This research was a combination research which included qualitative descriptive research to describe the implementation of adiwiyata programs using observation rubric instruments and quantitative descriptive research to describe the caring of environment of the teacher and student using instruments of questionnaire and interview guidelines. The results of the study showed that: (1) (a) Environmentally instightful school policies, includes the existence of a vision and mission related to the environment, 20\% RKAS for environmental programs. (b) Implementation of an environment based curriculum, covering planning and implementation of environmental education integrated subjects. (c) Participatory based environmental maintenance, extracurricular activities, creative and innovation, and cooperation with parents to government agencies. (d) Management of environmentally friendly supporting facilities, including facilities, maintenance of facilities, energy saving and healthy canteen service. (2) The results of the caring of environment of teachers and students at the Adiwiyata Junior High School at the provincial level were in the excellent category. The implementation of the adiwiyata program at the Adiwiyata Junior High School at the Provincial Level in Tanjungpinang in 2018 has been in accordance with the provincial level adiwiyata program determined by the Ministry of Environment and the Ministry of Education and Culture. These results are supported by the caring of environment for the teacher and students that very good.

Keywords: Implementation of Adiwiyata Program, Provincial level adiwiyata, Caring for the environment

*Penulis Korepondensi

Email Address : nurekakh2017@umrah.ac.id 


\section{PENDAHULUAN}

Lingkungan merupakan pemukiman tempat organisme hidup beserta segala keadaan dan kondisi di dalamnya yang secara langsung maupun tidak langsung mempengaruhi tingkat kehidupan organisme tersebut (Mundiatun \& Daryanto, 2015). Lingkungan yang mendukung kehidupan adalah lingkungan yang sehat. Namun, lingkungan fisik atau keadaan alam di Indonesia kini dalam keadaan memprihatinkan. Hal tersebut dikarenakan banyak terjadi fenomena kerusakan lingkungan yang berdampak pada kehidupan manusia.

Kerusakan lingkungan yang terjadi tak lepas dari ulah tangan manusia yang serakah dan mengeksploitasi lingkungan alam sehingga menyebabkan berbagai kerusakan. Iskandar, (2012) mengemukakan bahwa penebangan hutan, pembuangan sampah di sungai atau membuang sampah tidak pada tempatnya merupakan tingkah laku yang sering dilakukan warga Indonesia yang menyebabkan pencemaran dan kerusakan lingkungan. Permasalahan lingkungan yang terjadi di Indonesia bukan hanya mengenai sampah. Namun, permasalahan lain yang ada seperti kebakaran hutan, banjir dan tanah longsor.

Permasalahan lingkungan tidak hanya terjadi dalam lingkup nasional namun juga dalam lingkup yang lebih sempit khususnya dalam lingkungan pendidikan seperti kenakalan yang dilakukan siswa yang berhubungan dengan lingkungan diantaranya yaitu membuang sampah sembarangan. Bentuk kenakalan tersebut dilakukan dengan sengaja yang menunjukkan sikap tidak disiplin dan tidak peduli terhadap lingkungan. Sebagai contoh, ada siswa yang memanfaatkan kesempatan dalam kesempitan untuk membuang sampah tidak pada tempatnya. Permasalahan lain yang ditemukan yaitu mencoret-coret bangku sekolah, mencoretcoret toilet sekolah, aroma toilet yang tidak sedap, jajan di sekitar sekolah yang mengandung zat pewarna, zat pengawet, dan kurang bersih. Hal ini perlu mendapat perhatian dari guru sehingga dapat meminimalisir kerusakan-kerusakan lingkungan yang terjadi khususnya di sekolah. Selain itu, guru memiliki perhatian yang kuat dan memiliki sikap yang cinta terhadap lingkungan diharapkan dapat dijadikan contoh oleh siswa.

Fakta-fakta kerusakan lingkungan yang terjadi di Indonesia baik dalam lingkup nasional maupun di lingkungan sekolah menunjukkan bahwa kesadaran warga negara Indonesia akan pentingya menjaga lingkungan masih sangat kurang. Masnur (2011) menegaskan bahwa banyaknya kerusakan alam menunjukkan bahwa kesadaran pelajar untuk menjaga lingkungan masih rendah. Oleh karena itu pemerintah berkomitmen dalam menjaga lingkungan dari kerusakan melalui pendidikan. Salah satu program yang dikembangkan oleh Kementerian Lingkungan Hidup bekerjasama dengan Kementerian Pendidikan dan Kebudayaan adalah Program Adiwiyata. Kementerian Lingkungan Hidup dan Kementerian Pendidikan dan Kebudayaan (2012) menjelaskan bahwa Program Adiwiyata dimaknai sebagai program yang dilaksanakan dalam upaya untuk mewujudkan sekolah yang peduli dan berbudaya lingkungan. Tujuan program Adiwiyata adalah untuk mewujudkan warga sekolah yang bertanggung jawab dalam upaya perlindungan dan pengelolaan lingkungan hidup melalui tata kelola sekolah yang baik untuk mendukung pembangunan berkelanjutan.

Beberapa sekolah di Tanjungpinang telah menerapkan program adiwiyata. Ada yang telah mendapatkan penghargaan tingkat kota, provinsi, maupun nasional. Sekolah yang telah mencapai prestasi sebagai sekolah adiwiyata tingkat provinsi adalah sekolah yang telah lolos penilaian tingkat kota. Sikap peduli lingkungan warga sekolah yang telah menerapkan program adiwiyata diharapkan pada tingkatan minimal baik. Namun berdasarkan hasil observasi ternyata masih ditemui beberapa kendala atau permasalahan 
yang menunjukkan kurangnya kepedulian lingkungan warga sekolah walaupun telah mendapatkan predikat sekolah adiwiyata provinsi. Beberapa perilaku siswa yang menunjukkan kurangnya kepedulian terhadap lingkungan yaitu membuang sampah tidak pada tempatnya, misalnya di pot tanaman dan kurangnya sanksi yang diberikan kepada siswa yang kurang peduli lingkungan sehingga membuat siswa terus melakukan kesalahan yang sama. Berdasarkan uraian diatas, penulis tertarik untuk mengetahui bagaimana pelaksanaan program adiwiyata di SMPN adiwiyata tingkat provinsi serta mengetahui bagaimana sikap peduli lingkungan guru dan siswa di SMPN adiwiyata tingkat provinsi.

\section{METODE PENELITIAN}

Penelitian ini dilakukan dengan menggunakan metode deskriptif. Metode deskriptif digunakan untuk mendeskripsikan peristiwa atau kejadian yang menjadi pusat perhatian tanpa memberikan perlakuan khusus terhadap peristiwa tersebut (Noor, 2011). Pendekatan yang digunakan dalam penelitian ini adalah pendekatan kombinasi. (Sugiyono, 2016: 201), Metode penelitian kombinasi adalah metode yang menggunakan pengumpulan data dengan pengumpulan data kualitatif pada tahap pertama dan diikuti dengan pengumpulan data kuantitatif pada tahap kedua atau sebaliknya guna memperkuat hasil penelitian.

Data kualitatif tentang pelaksanaan program adiwiyata didapatkan dengan teknik observasi menggunakan rubrik observasi yang diadopsi dari kriteria penilaian program adiwiyata (Kementerian Lingkungan Hidup dan kementerian Pendidikan dan Kebudayaan, 2012). Sedangkan data kuantitatif berupa sikap peduli terhadap lingkungan guru dan siswa didapatkan dengan teknik survei menggunakan angket dan pedoman wawancara.

Penentuan sumber data guru dalam penelitian ini diambil dengan teknik random sampling, agar sampel yang diperoleh mewakili populasi. Sedangkan untuk menentukan sumber data siswa dalam penelitian ini diambil dengan teknik stratified random sampling (Sugiyono ,2016), yaitu cara mengambil sampel dengan memperhatikan strata (tingkatan) di dalam populasi. Strata yang dimaksud dalam penelitian ini adalah kelas VII, VIII, dan IX.

Seluruh instrumen divalidasi oleh ahli. Instrumen rubrik observasi meliputi aspek kebijakan berwawasan lingkungan, pelaksanaan kurikulum berbasis lingkungan, kegiatan lignkungan berbasis partisipatif, dan pengelolaan sarana dan prasarana ramah lingkungan. Instrumen angket sikap terdiri dari aspek kognitif, afektif, dan konatif.

\section{HASIL DAN PEMBAHASAN}

Berikut disajikan data mengenai pelaksanaan program adiwiyata di SMPN adiwiyata tingkat provinsi di Tanjungpinang serta sikap peduli lingkungan guru dan siswa di SMPN adiwiyata provinsi di Tanjungpinang.

A. Hasil Pelaksanaan Program Adiwiyata di SMPN Adiwiyata Tingkat Provinsi di Tanjungpinang.

Hasil pelaksanaan program adiwiyata di SMPN Adiwiyata Tingkat Provinsi di Tanjungpinang disajikan dalam Tabel 1, 2, 3,dan 4.

\section{a. Kebijakan Berwawasan Lingkungan}

Kebijakan berwawasan lingkungan merupakan salah satu standar program adiwiyata. Kebijakan berwawasan lingkungan adalah suatu kebijakan sebagai pedoman untuk mencapai target pendidikan lingkungan hidup. Arah dari kebijakan berwawasan lingkungan di sekolah sebagai pusat pemberdayaan nilai-nilai pengelolaan lingkungan melalui lembaga pendidikan serta meningkatkan partisipasi warga sekolah, orangtua maupun masyarakat. Sebagaimana tercantum dalam UU No 20 Tahun 2003 Tentang Sistem Pendidikan Nasional, bahwa salah satu arah kebijakan pendidikan di Indonesia adalah memberdayakan lembaga pendidikan baik 
JURNAL KIPRAH, Juli 2019; VII(1): 59-69

e-ISSN: 2580-6947

p-ISSN: 2354-7278

sekolah maupun luar sekolah sebagai pusat

pemberdayaan nilai, sikap, dan

kemampuan, serta meningkatkan

partisipasi keluarga dan masyarakat yang didukung oleh sarana dan prasarana yang memadai.

Tabel 1. Pelaksanaan Program Adiwiyata pada Aspek Kebijakan Berwawasan Lingkungan di SMPN Adiwiyata

Tingkat Provinsi di Tanjungpinang

\begin{tabular}{|l|l|l|}
\hline No. & \multicolumn{1}{|c|}{ Indikator } & \multicolumn{1}{c|}{ SMPN Adiwiyata Tingkat Nasional } \\
\hline 1. & $\begin{array}{l}\text { Kurikulum memuat upaya } \\
\text { perlindungan dan pengelolaan } \\
\text { lingkungan hidup }\end{array}$ & $\begin{array}{l}\text { Perumusan visi, misi, dan tujuan sekolah yang memuat } 2 \text { pengelolaan } \\
\text { lingkungan hidup. } \\
\text { Setiap mata pelajaran diintegrasikan dengan PPLH. } \\
\text { Adanya pengembangan diri terkait PPLH. }\end{array}$ \\
\hline 2. & $\begin{array}{l}\text { Rencana kegiatan dan anggaran } \\
\text { sekolah memuat program upaya } \\
\text { PPLH }\end{array}$ & $\begin{array}{l}\text { Sekolah memiliki anggaran untuk PPLH sebesar } \leq 20 \% \text { dari total } \\
\text { anggaran sekolah. }\end{array}$ \\
\hline
\end{tabular}

Tabel 1. Pelaksanaan Program Adiwiyata pada Aspek Pelaksanaan Kurikulum Berbasis Lingkungan di SMPN Adiwiyata Tingkat Provinsi di Tanjungpinang

\begin{tabular}{|c|c|c|}
\hline No. & Indikator & SMPN Adiwiyata Tingkat Nasional \\
\hline 1. & $\begin{array}{l}\text { Tenaga pendidik memiliki } \\
\text { kompetensi dalam mengembang } \\
\text { kan kegiatan pembelajaran } \\
\text { lingkungan } \\
\text { hidup. }\end{array}$ & $\begin{array}{l}\text { - }>70 \% \text { tenaga pendidik menerapkan metode yang melibatkan peserta } \\
\text { didik secara aktif. } \\
\text { - }>70 \% \text { tenaga pendidik mengembangkan indikator pembelajaran dan } \\
\text { instrumen penilaian yang terkait dengan perlindungan dan pengelolaan } \\
\text { lingkungan hidup. } \\
\text { - }>70 \% \text { tenaga pendidik menyusun rancangan pembelajaran } \\
\text { yang terkait dengan perlindungan dan pengelolaan lingkungan hidup. } \\
\text { - Hasil inovasi pembelajaran lingkungan hidup dikomunikasi-kan } \\
\text { sejumlah 4-6 media seperti majalah dinding, bulletin sekolah, pameran, } \\
\text { web-site, radio, TV, surat kabar \& jurnal. }\end{array}$ \\
\hline 2. & $\begin{array}{l}\text { Peserta didik melakukan kegiatan } \\
\text { pembelajaran tentang perlindungan } \\
\text { dan pengelolaan lingkungan hidup }\end{array}$ & $\begin{array}{l}\text { - } 30 \%-<50 \% \text { peserta didik menghasilkan karya nyata yang terkait } \\
\text { dengan perlindungan dan pengelolaan lingkungan hidup seperti gambar } \\
\text { dan produk daur ulang. } \\
\text { - } \geq 50 \% \text { peserta didik mempunyai kemampuan memecahkan masalah } \\
\text { lingkungan hidup. }\end{array}$ \\
\hline
\end{tabular}

Tabel 2. Pelaksanaan Program Adiwiyata pada Aspek Kegiatan Lingkungan Berbasis Partisipatif di SMPN Adiwiyata Tingkat Provinsi di Tanjungpinang

\begin{tabular}{|c|c|c|}
\hline No. & Indikator & SMPN Adiwiyata Tingkat Nasional \\
\hline 1. & 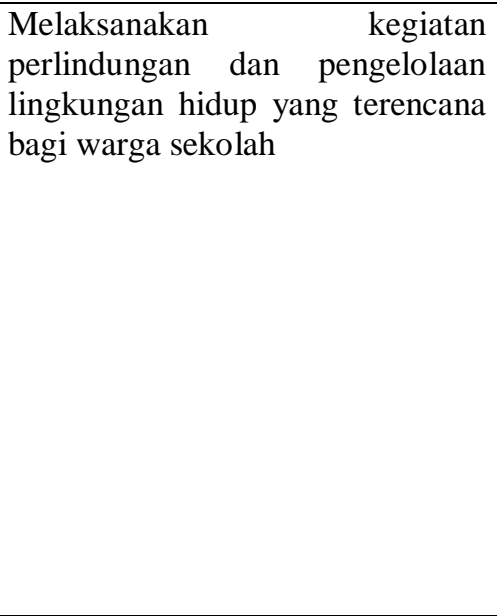 & $\begin{array}{l}\text { - } \geq 80 \% \text { warga sekolah terlibat dalam pemeliharaan gedung dan lingkungan } \\
\text { sekolah. } \\
\text { - } \geq 80 \% \text { warga sekolah memanfaatkan lahan dan fasilitas sekolah sesuai } \\
\text { kaidah-kaidah perlindungan dan pengelolaan lingkungan hidup } \\
\text { - } 60 \%-<80 \% \text { kegiatan ekstra kurikuler yang dimanfaatkan untuk } \\
\text { pembelajaran terkait dengan upaya perlindungan dan pengelolaan } \\
\text { lingkungan hidup. } \\
\text { - } 3-4 \text { kegiatan kreativitas dan inovasi warga sekolah dalam upaya } \\
\text { perlindungan dan pengelolaan lingkungan hidup seperti daur ulang } \\
\text { sampah, pemanfaatan sampah dan pengolahan air, karya ilmiah, karya seni } \\
\text { dan hemat energi. } \\
\text { - Tenaga pendidik mengikuti } \leq 6 \text { kegiatan aksi lingkungan hidup yang } \\
\text { dilakukan oleh pihak luar. } \\
\text { Peserta didik mengikuti } \leq 6 \text { kegiatan aksi lingkungan hidup yang } \\
\text { dilakukan oleh pihak luar. }\end{array}$ \\
\hline 2. & $\begin{array}{l}\text { Menjalin kemitraan dalam rangka } \\
\text { perlindungan dan pengelolaan } \\
\text { lingkungan hidup dengan } \\
\text { berbagai pihak (masyarakat, } \\
\text { pemerintah, swasta, media, } \\
\text { sekolah lain) }\end{array}$ & $\begin{array}{l}\text { - } 2 \text { mitra yang dimanfaatkan sebagai narasumber untuk meningkatkan } \\
\text { pembelajaran lingkungan hidup. } \\
\text { - } 2 \text { mitra yang mendukung dalam bentuk materi untuk kegiatan yang terkait } \\
\text { dengan upaya perlindungan dan pengelolaan lingkungan hidup. } \\
\text { - } 2 \text { kemitraan yang difasilitasi oleh komite sekolah terkait dengan } \\
\text { pembelajran lingkungan hidup dan upaya perlindungan dan pengelolaan }\end{array}$ \\
\hline
\end{tabular}




\begin{tabular}{|l|l|l|}
\hline & $\begin{array}{l}\text { lingkungan hidup. } \\
\leq 3 \text { kali menajdi narasumber dalam rangka pembelajaran lingkungan hidup } \\
\leq 3 \text { kali dukungan yang diberikan sekolah dalam upaya perlindungan dan } \\
\text { pengelolaan lingkungan hidup. }\end{array}$ \\
\hline
\end{tabular}

Tabel 3. Pelaksanaan Program Adiwiyata pada Aspek Pengelolaan Sarana Pendukung Ramah Lingkungan di SMPN Adiwiyata Tingkat Provinsi di Tanjungpinang

\begin{tabular}{|c|l|l|}
\hline No. & \multicolumn{1}{|c|}{ Indikator } & \multicolumn{1}{c|}{ SMPN Adiwiyata Tingkat Nasional } \\
\hline 1. & $\begin{array}{l}\text { Ketersediaan sarana prasarana pendukung } \\
\text { yang ramah lingkungan }\end{array}$ & $\begin{array}{l}\text { Tersedianya } \geq 6 \text { sarana prasarana untuk mengatasi permasalahan } \\
\text { lingkungan hidup di sekolah sesuai dengan standar sarana dan } \\
\text { prasana. } \\
\text { Tersedianya } \geq 6 \text { sarana prasarana pendukung pembelajaran } \\
\text { lingkungan hidup. }\end{array}$ \\
\hline 2. & $\begin{array}{l}\text { Peningkatan kualitas pengelolaan sarana dan } \\
\text { prasarana yang ramah lingkungan di sekolah }\end{array}$ & $\begin{array}{l}\text { Terpelihara 3 sarana dan prasana yang ramah lingkungan sesuai } \\
\text { fungsinya. } \\
\text { Tersedianya 4 unsur mekanisme pengelolaan dan pemeliharaan } \\
\text { sarana seperti penanggung jawab, pelaksana, pengawas dan tata } \\
\text { tertib. } \\
15 \% \text { - <20\% efisiensi pemanfaatan listrik, air dan alat tulis } \\
\text { kantor. }\end{array}$ \\
& $\begin{array}{l}\text { Kantin melakukan 3 upaya peningkatan kualitas pelayanan } \\
\text { kantin sehat dan ramah lingkungan. }\end{array}$ \\
\hline
\end{tabular}

Keberhasilan dan kegagalan suatu proses pelaksanaan kebijakan memiliki beberapa faktor yang mempengaruhinya. Hal ini sesuai dengan pendapat Rohman (2009) mengatakan bahwa ada tiga faktor yang menentukan kegagalan dan keberhasilan dalam implementasi kebijakan, yaitu: perumusan kebijakan, personil pelaksana dan sistem organisasi pelaksana. Dalam hal ini tiga faktor tersebut haruslah selaras agar tujuan yang dingin dicapai dapat terlaksana dengan baik.

Berikut pembahasan mengenai hasil penelitian terkait aspek kebijakan berwawasan lingkungan di sekolah SMPN adiwiyata tingkat provinsi

a) Visi, Misi dan tujuan sekolah yang tertuang dalam kurikulum memuat kebijakan perlindungan dan pengelolaan lingkungan hidup.

Berdasarkan hasil penelitian, pelaksanaan kebijakan berwawasan lingkungan disekolah SMPN adiwiyata tingkat provinsi telah dilaksanakan sesuai dengan panduan adiwiyata. Hal tersebut ditandai dengan visi misi dan tujuan sekolah sudah sesuai dengan nilai-nilai upaya perlindungan dan pengelolaan lingkungan hidup. Visi misi dan tujuan tersebut juga sudah diketahui dan dipahami oleh hampir semua warga sekolah baik dari guru, siswa, staf, karyawan, maupun komite sekolah.

b) Struktur kurikulum memuat muatan lokal, pengembangan diri terkait kebijakan perlindungan dan pengelolaan lingkungan hidup.

Berdasarkan hasil penelitian poin kedua ini belum sepenuhnya terlaksana. Hal tersebut terlihat bahwa tidak terdapat muatan lokal mengenai pendidikan lingkungan hidup. Hanya mengintegrasikan nilai-nilai lingkungan kedalam mata pelajaran serta adanya pengembangan diri yang terkait dengan lingkungan yaitu seperti cinta lingkungan. Serta mata pelajaran dan pengembangan diri tersebut memiliki ketuntasan minimal belajar tersendiri.

c) Rencana kegiatan dan Anggaran sekolah (RKAS) memuat program dalam upaya perlindungan dan pengelolaan lingkungan hidup.

Berdasarkan hasil penelitian Rencana kegiatan dan Anggaran sekolah (RKAS) SMP Negeri program adiwiyata tingkat provinsi dialokasikan sebesar $>20 \%$ dari total anggaran 


\section{JURNAL KIPRAH, Juli 2019; VII(1): 59-69 \\ e-ISSN: 2580-6947 \\ p-ISSN: 2354-7278}

sekolah untuk program perlindungan dan pengelolaan lingkungan hidup. Program tersebut meliputi: kesiswaan, kurikulum dan kegiatan pembelajaran, peningkatan kapasitas, sarana dan prasarana, budaya dan longkungan sekolah, peran masyarakat dan kemitraan, serta peningkatan dan pengembangan mutu.

Berdasarkan komponen adiwiyata yang pertama yaitu kebijakan berwawasan lingkungan belum sepenuhnya terlaksana sesuai dengan panduan adiwiyata. Dari visi, misi dan tujuan, struktur kurikulum serta anggaran sekolah. Sehingga dapat disimpulkan bahwa pelaksanaan komponen adiwiyata yang pertama pada aspek kebijakan berwawasan lingkungan pada SMP Negeri program adiwiyata tingkat nasional sudah baik.

\section{b. Pelaksanaan Kurikulum Berbasis Lingkungan}

Kurikulum berbasis lingkungan juga merupakan standar kedua program adiwiyata, kurikulum ini memuat tentang materi pengelolaan dan perlindungan terhadap lingkungan hidup yang disampaikan dengan berbagai cara dalam upaya memberikan pemahaman mengenai lingkungan hidup. Kurikulum berbasis lingkungan dikembangkan oleh sekolah dalam upaya perlindungan dan pengelolaan lingkungan dengan cara diintegrasikan kedalam mata pelajaran.

a) Tenaga pendidik memiliki kompetensi dalam mengembangkan kegiatan pembelajaran lingkungan hidup.

Berdasarkan hasil penelitian guru sebagai pendidik telah menerapkan metode yang melibatkan siswa secara aktif dengan menggunakan metode seperti berdiskusi, pengalaman lapangan, debat, observasi dan lain-lain. Guru selaku tenaga pendidik harus menciptakan suasana belajar yang kondusif. Hal tersebut sebagaimana yang diungkapkan oleh Tim Dosen AP UPI (2013) hendaknya tidak menerapkan satu metode, namun guru harus dapat menerapkan berbagai metode agar proses pembelajaran berlangsung dengan menyenangkan dan mencapai sasaran yang direncanakan. Sebagian besar guru telah memiliki kompetensi adiwiyata sesuai standar adiwiyata yang ada. Hal tersebut sebagaimana yang tercantum dalam buku Panduan Adiwiyata (2012) bahwa tenaga pendidik harus mampu mengembangkan indikator dan instrumen pembelajaran lingkungan hidup.

Pada SMP Negeri program adiwiyata tingkat nasional dan provinsi $>50 \%$ guru mampu mengembangkan isu atau permasalahan mengenai lingkungan hidup ke dalam materi pembelajaran, sehingga peserta didik dapat memecahkan permasalahan lingkungan dalam kehidupan sehari-hari. Selain pembelajaran di kelas, guru juga mengembangkan kegiatan pembelajaran di luar kelas. Guru juga tentunya mampu menyusun rancangan pembelajaran agar proses pembelajaran berjalan sesuai dengan yang diharapkan. Dalam kegiatan pembelajaran tentunya juga dilakukan evaluasi sesuai yang telah dirancang dalam Rencana Pelaksanaan Pembelajaran (RPP). Evaluasi pembelajaran ditujukan untuk mengetahui apakah tujuan kurikulum telah tercapai atau belum. Hal tersebut senada dengan Sukmadinata (2010) mengatakan evaluasi ditujukan untuk menilai pencapaian tujuan-tujuan yang telah ditentukan serta menilai proses pelaksanaan mengajar secara keseluruhan.

b) Peserta didik melakukan kegiatan pembelajaran tentang perlindungan dan pengelolaan lingkungan hidup.

Berdasarkan hasil observasi pada SMPN program adiwiyata tingkat nasional $>50 \%$ siswa menghasilkan karya nyata terkait dengan perlindungan dan pengelolaan lingkungan hidup seperti gambar, produk daur ulang dan lainnya. Artinya sebagian besar siswa sudah mampu menghasilkan karya nyata mengenai perlindungan dan pengelolaan lingkungan hidup. Selain menghasilkan karya nyata siswa juga dituntut harus mampu memecahkan masalah lingkungan hidup, di SMPN adiwiyata 
tingkat nasional $>50 \%$ telah mempunyai kemampuan memecahkan masalah lingkungan hidup, hal ini terbukti bahwa ketika guru memberikan suatu permasalahan mengenai lingkungan hidup siswa dapat memecahkan permasalahn tersebut.

Dari hasil penelitian terkait komponen kedua yaitu pelaksanaan kurikulum berbasis lingkungan sudah dilaksanakan dengan baik oleh SMPN adiwiyata tingkat provinsi. Sebagian besar guru dan siswa telah menerapkan adiwiyata pada saat pembelajaran.

\section{c. Kegiatan Lingkungan Berbasis Partisipatif}

Kegiatan lingkungan berbasis partisipatif adalah kegiatan yang melibatkan warga sekolah dan masyarakat di sekitarnya melakukan berbagai kegiatan yang memberikan manfaat baik warga sekolah, masyarakat maupun lingkungan dalam rangka kegiatan pengelolaam lingkungan hidup.

Berdasarkan hasil observasi pada standar yang pertama dalam kegiatan berbasis partisipatif adalah memelihara dan merawat gedung lingkungan sekolah oleh warga sekolah. Dalam standar ini pada SMPN program adiwiyata tingkat provinsi $>80 \%$ warga sekolah atau hampir seluruh warga sekolah terlibat dalam pemeliharaan gedung dan lingkungan sekolah bentuk kegiatan yang dilaksanakan seperti piket kebersihan kelas, lomba kebersihan kelas, gotong royong, lomba kebersihan kelas, kegiatan pemeliharaan taman, dan lain-lain. Kemudian standar yang kedua adalah memanfaatkan lahan dan fasilitas sesuai kaidah-kaidah lingkungan hidup seperti: pembuatan green house, screen house dan taman. Selanjutnya standar yang ketiga yaitu mengembangkan kegiatan ekstrakurikuler yang sesuai dengan upaya perlindungan dan pengelolaan lingkungan hidup, selain diintegrasikan di dalam mata pelajaran, SMPN adiwiyata tingkat provinsi juga mengembangkan kegiatan ekstrakurikuler yang sesuai dengan upaya perlindungan dan pengelolaan lingkungan hidup seperti: pembuatan kompos dan daur ulang sampah. Hal ini dilakukan untuk mengembangkan karakter cinta lingkungan.

Kegiatan ekstrakurikuler di sekolah dilakukan pada jam diluar pembelajaran. Hal tersebut sesuai dengan Tim Dosen AP UPI (2013: 212) mengemukakan bahwa kegiatan ekstrakurikuler adalah semua kegiatan yang telah ditentukan di dalam kurikulum yang pelaksanaannya dilakukan pada luar jam-jam pelajaran. Hal tersebut menghindari agar tidak terjadi masalah dalam penggunaan sarana pendukung.

Pengembangan ekstrakurikuler lebih mengarah kepada pembinaan potensi siswa dan pembiasaan cinta lingkungan. Kemudian standar yang ketiga yaitu adanya kreatifitas dan inovasi warga sekolah dalam upaya perlindungan dan pengelolaan lingkungan hidup. Pada SMPN adiwiyata tingkat provinsi telah melakukan 3-4 kegiatan kreativitas dan inovasi dalam upaya perlindungan dan pengelolaan lingkungan hidup seperti; daur ulang sampah, pemanfaatan sampah, pengolahan air, karya seni dan hemat energi. Kemudian standar yang terakhir yaitu mengikuti kegiatan aksi lingkungan hidup yang dilakukan oleh pihak luar. SMPN program adiwiyata tingkat provinsi telah mengikuti lebih dari 5 kali kegiatan aksi lingkungan, baik guru maupun siswa.

Berdasarkan hasil observasi mengenai kegiatan lingkungan berbasis partisipatif, sekolah sudah menjalankannya dengan baik sesuai dengan peraturan panduan adiwiyata.

\section{d. Pengelolaan Sarana Pendukung Ramah Lingkungan \\ SMPN adiwiyata tingkat provinsi dalam} upaya mewujudkan sekolah yang peduli dan berbudaya lingkungan perlu didukung sarana dan prasarana yang mencerminkan upaya perlindungan dan pengelolaan lingkungan hidup, antara lain standarnya: ketersediaan 


\section{JURNAL KIPRAH, Juli 2019; VII(1): 59-69 \\ e-ISSN: 2580-6947 \\ p-ISSN: 2354-7278}

sarana prasarana pendukung yang ramah lingkungan dan peningkatan kualitas pengelolaan dan pemanfaatan sarana dan prasarana yang ramah lingkungan. Indikator pertama pada standar ketersediaan sarana dan prasarana pendukung ramah lingkungan yaitu menyediakan sarana prasarana untuk mengatasi permasalahan lingkungan hidup di sekolah, sekolah telah menyediakan $>6$ sarana dan prasarana tersebut yaitu seperti: tempat sampah (penyediaan tempat sampah terpisah), air bersih, drainase, lubang biopori, tempat tinja, dan lain-lain. Selanjutnya indikator kedua yaitu menyediakan sarana dan prasarana untuk mendukung pembelajaran lingkungan hidup disekolah. Kedua sekolah tersebut telah menyediakan $>6$ sarana prasarana pendukung pembelajaran lingkungan hidup, seperti: pengomposan, pemanfaatan dan pengolahan air, taman/kebun sekolah, green house, screen house, tanaman obat keluarga, kolam ikan dan lain-lain.

SMPN program adiwiyata tingkat provinsi telah memanfaatkan $>15 \%$ efesiensi pemanfaatan listrik, air dan alat tulis kantor artinya sekolah ini sudah baik dalam penghematan energi. Kemudian indikator yang terakhir yaitu meningkatkan kualitas pelayanan kantin sehat dan ramah lingkungan. Sekolah tersebut telah melakukan 3 upaya kantin sehat dan ramah lingkungan

Berdasarkan kesimpulan hasil observasi mengenai pengelolaan sarana dan prasarana ramah lingkungan pada kedua sekolah sudah sangat baik dengan menerapkan aturan-aturan sesuai dengan panduan adiwiyata. Menurut Engkoswara (2011) bahwa sarana dan prasarana atau fasilitas pendidikan merupakan hal yang sangat penting dalam penyelenggaraan pendidikan yang berfungsi memberikan kemudahan-kemudahan bagi siswa, guru, maupun ketenaga pendidikan lainnya yang berupa gedung, ruangan kelas, perumahan guru, penjaga sekolah dan gedung laboratorium.
B. Sikap Peduli Lingkungan Guru dan Siswa Pada Program Adiwiyata di SMP Negeri Adiwiyata Tingkat Provinsi di Tanjungpinang

Hasil penelitian mengenai sikap peduli lingkungan guru dan siswa pada program adiwiyata di SMPN adiwiyata tingkat nasional di Tanjungpinang diperoleh melalui data utama berupa angket. Pada angket sikap digunakan 25 pernyataan yang disesuaikan berdasarkan aspek dan indikatornya. Adapun hasil persentase pernyataan setiap aspek (kognitif, afektif, dan konatif) disajikan pada Gambar 1 dan 2 .

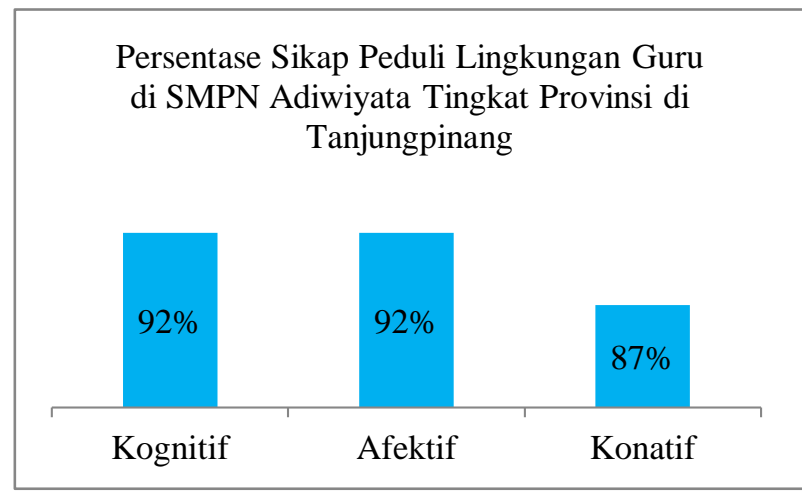

Gambar 1. Diagram Persentase Sikap Peduli Lingkungan Guru di SMPN Adiwiyata Tingkat Provinsi di Tanjungpinang

Persentase Sikap Peduli Lingkungan Siswa di SMPN Adiwiyata Tingkat Provinsi di Tanjungpinang

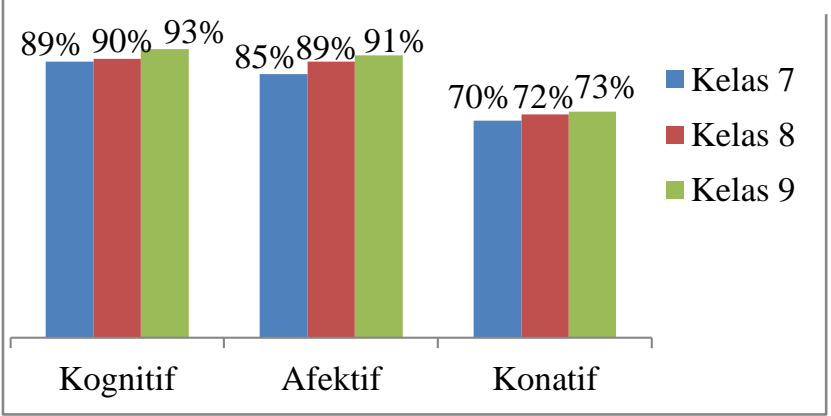

Gambar 2. Diagram Persentase Sikap Peduli Lingkungan Siswa di SMPN Adiwiyata Tingkat Provinsi di Tanjungpinang 


\section{a. Kognitif}

Aspek kognitif dalam penelitian ini yaitu hal yang berkaitan dengan pengetahuan mengenai sikap peduli lingkunga pada program adiwiyata. Hal ini sejalan dengan penelitian (Kusumaningtias, 2017), faktor kognitif yaitu komponen yang berkaitan dengan pengetahuam, pandangan, dan keyakinan terhadap objek. Berdasarkan hasil penelitan yang telah dijabarkan di atas, hasil sikap peduli lingkungan aspek kognitif guru pada SMPN adiwiyata tingkat provinsi yaitu $92 \%$ dikategorikan sangat baik . Hal ini menyatakan bahwa guru di SMPN adiwiyata tingkat provinsi telah memiliki pengetahuan yang baik mengenai program adiwiyata. Guru telah mengetahui apa itu program adiwiyata, tujuan program adiwiyata, manfaat program adiwiyata, prinsip program adiwiyata serta komponen program adiwyata, hal ini terlihat dari lembar angket, rata-rata guru memilih jawaban sangat setuju pada beberapa pernyataan dan didukung dengan hasil wawancara.

Hasil sikap peduli lingkungan pada aspek kognitif siswa pada SMPN adiwiyata tingkat provinsi yaitu $91 \%$ dikategorikan sangat baik. Dengan persentase siswa kelas 7 yaitu $89 \%$, kelas 8 yaitu $90 \%$ dan kelas 9 yaitu 93\%. Terlihat dari segi tingkatan kelas bahwa semakin tinggi kelas maka semakin tinggi pula hasil nya, hal ini dikarenakan beberapa faktor seperti siswa yang semakin tinggi tingkatan kelas nya maka pengetahuan yang telah dimilikinya semakin banyak dan sudah banyak pengalaman yang telah dilalui. Pembelajaran mengenai lingkungannya juga lebih dalam, kemudian telah banyak mengikuti kegiatankegiatan yang dilaksanakan. Sehingga terlihat dari apa yang telah diamati bahwa siswa kelas 9 memiliki sikap peduli lingkungan pada aspek kognitif yang lebih tinggi dibandikan siswa kelas 8 dan kelas 7. Hal ini sejalan dengan penelitian yang dilakukan oleh (Fitriani, 2017) bahwa tingkat pendidikan berpengaruh terhadap pengetahuan seseorang, dimana semakin tinggi tingkat pendidikan maka pengetahuan yang dimiliki semakin baik.

\section{b. Afektif}

Aspek afektif dalam penelitian ini yaitu hal yang berkaitan dengan sikap terhadap program adiwiyata. Berdasarkan hasil penelitan yang telah dijabarkan di atas, hasil sikap peduli lingkungan pada aspek afektif guru pada SMPN program adiwiyata tingkat provinsi yaitu $92 \%$ dikategorikan sangat baik. Hal ini menyatakan bahwa guru di SMPN program adiwiyata tingkat provinsi telah memiliki sikap yang sangat baik terhadap lingkungan. Guru rata-rata memilih jawaban sangat setuju pada pernyataan-pernyataan aspek afektif. Berdasarkan hasil angket dan jawaban wawancara dapat diperoleh kesimpulan bahwa guru sangat peduli dengan lingkungan sekitarnya dengan membuang sampah pada tempatnya, kemudian memiliki sikap bertanggung jawab, selalu bekerja sama baik dengan guru, siswa maupun warga sekolah lainnya untuk medukung program adiwiyata, memberikan inovasi untuk menyukseskan kegiatan adiwiyata, guru juga bersikap responsif, proaktif serta ikhlas dalam menjalankan kegiatan adiwiyata ini.

Hasil sikap peduli lingkungan pada aspek afektif siswa pada SMPN adiwiyata tingkat provinsi yaitu $89 \%$ dikategorikan sangat baik. Dengan persentase siswa kelas 7 yaitu $85 \%$, kelas 8 yaitu $89 \%$ dan kelas 9 yaitu 91\%. Dari hasil yang telah dijabarkan berdasarkan tingkatan kelas, baik SMPN adiwiyata tingkat nasional maupun tingkat provinsi terlihat bahwa kelas 9 memiliki persentase lebih tinggi dibandingkan kelas 8 dan kelas 7. Hal ini karena siswa kelas 9 memiliki sikap yang lebih menonjol dibandingkan kelas 8 dan kelas 7, hal ini dibuktikan dari hasil angket dan hasil wawancara, bahwa berdasarkan angket yang diperoleh kelas 9 lebih banyak memilih jawaban sangat setuju dibandingkan dua kelas 


\section{JURNAL KIPRAH, Juli 2019; VII(1): 59-69 \\ e-ISSN: 2580-6947 \\ p-ISSN: 2354-7278}

lainnya. Berdasarkan hasil wawancara juga kelas 9 memiliki aspek sikap peduli lingkungan yang lebih baik dibandingkan kelas 8 dan kelas 9.

\section{c. Konatif}

Aspek konatif dalam penelitian ini yaitu hal yang berkaitan dengan prilaku terhadap lingkungan pada program adiwiyata. Berdasarkan hasil penelitan yang telah dijabarkan di atas, hasil sikap peduli lingkungan pada aspek konatif guru pada SMPN program adiwiyata tingkat provinsi yaitu $87 \%$ dikategorikan sangat baik. Berdasarkan hasil angket, rata-rata guru memilih jawaban sangat sering dalam kegiatan yang berkaitan dengan lingkungan. Berdasarkan hasil wawancara guru juga mengungkapkan selalu melakukan kegiatan yang berkaitan untuk menyukseskan kegiatan program adiwiyata. Misalnya dengan selalu menjaga kebersihan lingkungan, kemudian ketika membuang sampah selalu dibedakan antara sampah organik, anorganik dan sampah B3, sering mengikuti kegiatan serta membimbing siswa dalam kegiatan lingkungan seperti pengomposan, gotong royong, penghijauan dan hal-hal yang berkaitan dengan lingkungan, serta selalu berpartisipasi dalam pengurangan penggunaan plastik seperti dengan membawa cangkir atau botol dari rumah kemudian mengikuti serta membimbing siswa dalam mendaur ulang sampah plastik.

Hasil sikap peduli lingkungan pada aspek konatif siswa pada SMPN adiwiyata tingkat provinsi yaitu $71 \%$ dikategorikan baik. Dengan persentase siswa kelas 7 yaitu $70 \%$, kelas 8 yaitu $72 \%$ dan kelas 9 yaitu $73 \%$. dikategorikan baik. Dari hasil yang telah dijabarkan berdasarkan tingkatan kelas, baik SMPN program adiwiyata tingkat provinsi terlihat bahwa kelas 9 memiliki persentase lebih tinggi dibandingkan kelas 8 dan kelas 7 . Hal ini karena siswa kelas 9 lebih sering mengikuti kegiatan adiwiyata dibandingkan kelas 8 dan kelas 7 , karena kelas 9 lebih dahulu di sekolah tersebut dibandingkan kelas 8 dan kelas 7 sehingga kelas 9 lebih banyak berpasrtisipasi dibandingkan kedua kelas tersebut. Hal ini sejalan dengan penelitian yang dilakukan oleh Fitriani (2017) dijelaskan bahwa pengetahuan adalah faktor dominan yang mempengaruhi prilaku, dimana seseorang akan berperilaku sesuai dengan pengetahuannya

\section{KESIMPULAN}

Berdasarkan hasil penelitian dan pembahasan yang telah dipaparkan di atas, disimpulkan bahwa pelaksanaan program adiwiyita pada SMPN program adiwiyata tingkat provinsi di Tanjungpinang sudah berjalan sangat baik hasil penelitian menujukkan bahwa:

1. Pada aspek kebijakan berwawasan lingkungan sudah terlaksana dengan memuat visi misi terkait kebijakan upaya perlindungan dan pengelolaan lingkungan hidup, adanya alokasi dana untuk program adiwiyata, kurikulum berwawasan lingkungan dilaksanakan dengan mengintegrasikan materi wawasan lingkungan ke dalam mata pelajaran. (2) Pada aspek pelaksanaan kurikulum berbasis lingkungan juga telah dilaksanakan yaitu guru memunculkan isu lokal terkait lingkungan hidup pada setiap mata pelajaran, proses penerapan kurikulum berbasis lingkungan juga didukung oleh pembuatan rencana pembelajaran dan instrumen evaluasi yang memuat upaya pengelolaan dan perlindungan lingkungan. (3) Pada aspek kegiatan lingkungan berbasis partisipatif dilaksanakan melalui berbagai aksi lingkungan baik yang diselenggarakan dari sekolah maupun instansi dari luar sekolah. (4) Pada aspek pengelolaan sarana pendukung ramah lingkungan, sekolah telah menyediakan sarana dan prasarana pendukung yang ramah 
lingkungan seperti tempat sampah terpisah, green house, rumah kompos, sumur resapan, dan lain-lain serta pengelolaan kantin, pengelolaan air, listrik, dan ATK secara efisien.

2. Sikap peduli lingkungan guru dan siswa di SMPN adiwiyata tingkat provinsi yang dikategorikan sangat baik dapat diasumsikan merupakan modal ataupun dampak positif dari pelaksanaan program adiwiyata yang sudah mencapai tingkat provinsi.

\section{REFERENSI}

Engkoswara \& Komariah, A. 2011. Administrasi Pendidikan. Bandung: Alfabeta.

Fitriani, R. 2017. Perilaku Peduli Lingkungan Pada Siswa Kelas X SMA Muhammadiyah 1 Yogyakarta. Skripsi: Universitas Negeri Yogyakarta.

Kementerian Lingkungan Hidup dengan Kementerian Pendidikan dan Kebudayaan, 2012. Panduan Adiwiyata Sekolah Peduli dan Berbudaya Lingkungan, Jakarta: Kementerian Lingkungan Hidup.

Kusumaningtias, L., 2017, Sikap Siswa Kelas Atas Terhadap Pembelajaran Pendidikan Jasmani di SDN 3 Pengasih, Skripsi, Universitas Yogyakarta.

Masnur, M. 2011. Pendidikan Karakter Menjawab Tantangan Krisis Multidimensional Jakarta: Bumi Aksara.

Mundiatun \& Daryanto. 2015. Pengelolaan Kesehatan Lingkungan, Yogyakarta: Gava Media.

Noor, J. 2012. Metodologi Penelitian. Jakarta: Kencana Prenada Media Group.

Rohman, A. 2009. Politik Ideologi Pendidikan. Yogyakarta: Laksbang Mediatama.
Sugiyono. 2016. Metode Penelitian Kombinasi (Mixed Methods). Bandung : Alfabeta. Sukmadinata, N,S., 2010, Metode Penelitian Pendidikan, Remaja Rosdakarya, Bandung.

Tim Dosen Administrasi Pendidikan Universitas Pendidikan Indonesia. 2013. Manajemen Pendidikan. Bandung: Alfabeta.

Zulriska, R. 2012. Psikologi Lingkungan: Teori dan Konsep, Bandung: PT Refika Aditama. 